\title{
GOOD CORAL GOVERNANCE (INOVASI PENGELOLAAN TERUMBU KARANG) KABUPATEN WAKATOBI
}

\author{
La Radu1, Andi Luhur Prianto'1, Muchlas M. Tahir¹ \\ ${ }^{1}$ Program Studi Ilmu Pemerintahan Fakultas Ilmu Sosial dan Ilmu Politik \\ Universitas Muhammadiyah Makassar \\ Jl. Sultan Alauddin No. 259 Makassar 90221 \\ Telp. 0411-866972 ext.107.Fax.0411-8655888 \\ laradu@yahoo.co.id, luhur@unismuh.ac.id muchlasmtahir@gmail.com
}

\begin{abstract}
The purpose of this study aims to determine the innovation management of coral reefs in the perspective of governance and to determine the factors supporting and inhibiting innovation coral reef management by local governments. This type of research is descriptive qualitative. The results showed the involvement of stakeholders in transplanting corals and supervision in the field of conservation of marine protected areas, there is a match between local knowledge and modern knowledge. Supervision and control is carried out by the Ministry of Maritime Affairs and Fisheries, Marine and Fisheries Agency well as the community watchdog group. Surveillance and monitoring operations have been allocated budgets of state and local budgets. Authority management refers to the laws, ministerial regulations, local regulations, village regulations and the values of local wisdom .
\end{abstract}

Keywords : governance, coral reefs, innovation

\begin{abstract}
ABSTRAK
Tujuan penelitian ini bertujuan untuk mengetahui inovasi pengelolaan terumbu karang dalam persfektif tata kelola dan untuk mengetahui faktor pendukung dan penghambat dalam inovasi pengelolaan terumbu karang yang dilakukan oleh pemerintah daerah. Tipe penelitian ini deskriptif kualitatif. Hasil penelitian menunjukkan adanya keterlibatan para pemangku kepentingan dalam melakukan transplantasi karang dan pengawasan dibidang konservasi daerah perlindungan laut, terdapat kesesuaian antara pengetahuan lokal dan pengetahuan modern. Pengawasan dan pengendalian dilakukan oleh kementerian Kelautan dan Perikanan, dinas kelautan dan perikanan serta kelompok masyarakat pengawas. Operasi pengawasan dan pemantauan mendapat alokasi anggaran dari APBN dan APBD. Otoritas pengelolaan mengacu kepada undang-undang, peraturan menteri, peraturan daerah, peraturan desa serta nilai-nilai kearifan lokal.
\end{abstract}

Kata kunci : tata kelola, terumbu karang, inovasi 


\section{A. PENDAHULUAN}

Indonesia adalah negara kepulauan terbesar di dunia, dan memiliki lebih dari 17.000 pulau membentang di khatulistiwa, garis pantai lebih dari $95.000 \mathrm{~km}$. Adapun, luas lautan 5,8 juta km (75\% dari total luas wilayah Indinesia). Di wilayah daratan terdapat perairan umum (sungai, rawa, danau, waduk, dan genangan air lainnya) seluas 54 juta ha atau 0,54 juta $\mathrm{km}^{2}(27 \%$ dari total wilayah daratan Indonesia). Dengan demikian, Indonesia adalah sebuah negara yang dikelilingi oleh air. (Kordi, 2010).

Berdasarkan penelitian pada tahun 1998, luas terumbu karang Indonesia adalah 42.000 $\mathrm{km}^{2}$ atau $16,5 \%$ dari luasan terumbu karang dunia yaitu seluas $255.300 \mathrm{~km}^{2}$ dengan 70 genera dan 450 spesies (Gatot, 2008). Menurut Dahuri (dalam Kordi, 2010) dengan meminjam judul sebuah film, menyebut Indonesia sebagai a water world. Luas Indonesia dengan lautnya sama dengan Amerikat Serikat (AS) dan lebih luas dari Uni Eropa. Perbedaannya, Indonesia terdiri atas puluhan ribu pulau di sebuah wilayah lautan yang sangat luas sementara AS adalah sebuah negara daratan dan Eropa terdiri atas banyak negara banyak daratan.

Menurut hasil penelitian Pusat Pengembangan Oseanologi (P20) LIPI yang dilakukan pada tahun 2000, kondisi terumbu karang Indonesia 41,78\% dalam keadaan rusak, 28,30 \% dalam keadaan sedang, 23,72 $\%$ dalam keadaan baik, dan 6,20 \% dalam keadaan sangat baik. Hal ini menunjukkan telah terjadi tekanan yang cukup besar terhadap keberadaan terumbu karang di Indonesia pada umumnya oleh berbagai ancaman dan faktor-faktor penyebab kerusakan.

Selanjutnya penelitian yang dikoordinir oleh World Resource Institute (WRI) di 14 negara di Asia Tenggara, dilakukan pada tahun 2002, menemukan bukti-bukti bahwa $88 \%$ dari sekitar $95.790 \mathrm{~km}^{2}$ terumbu karang telah berada pada posisi resiko kerusakan yang berat. Ancaman dan proses kerusakan ini disebabkan karena pembangunan pesisir secara tidak terkendali dan terencana dengan baik, polusi yang berasal dari darat, sedimentasi yang disebabkan karena erosi di daratan, penangkapan ikan secara berlebihan, penggunaan teknologi destruktif dalam penangkapan ikan, dan perubahan iklim serta pemutihan karang (coral bleaching).

Secara khusus di Indonesia, laporan ini mengemukakan kondisi rusak dan ancaman kerusakan terumbu karang sekitar $95 \%$ dari $39.500 \mathrm{~km}^{2}$ luasan terumbu karang Indonesia, sekitar 16\% dari luasan terumbu karang dunia. Selain pada skala nasional, kerusakan terumbu karang dibuktikan dengan kondisinya di beberapa lokasi. Sebagai contoh, pada tahun 1982, terdapat sebanyak 226 spesies (56 genus) terumbu karang di Teluk Ambon, kemudian terdegradasi menjadi 176 spesies (54 genus) pada tahun 2003. Sahetapy (dalam Victor, 2013).

Demikian juga halnya dengan Kabupaten Wakatobi, Sulawesi Tenggara. Kawasan ini juga mempunyai potensi sumber daya alam pesisir dan lautan serta jasa-jasa lingkungan khususnya terumbu karang, yang memiliki prospek perekonomian yang mampu untuk mendorong pertumbuhan dan pengembangan pemukiman dan kegiatan ekonomi serta sosial lainnya.

Namun potensi sumberdaya alam berupa terumbu karang yang ada di Wakatobi belum sepenuhnya optimal dan pemanfaatan keindahan terumbu karang termasuk juga masih minimnya ketersediaan fasilitas untuk menopang dalam menjaga dan mengawasi kelestarian terumbu karang dari berbagai ancaman kegiatan manusia berupa penangkapan ikan secara berlebihan dengan menggunakan pemboman atau hal-hal lain yang dapat menimbulkan degradasi tekanan (kerusakan) terhadap kondisi terumbu karang di kawasan tersebut.

Hal ini kurangnya kesadaran dari masyarakat akan pentingnya pelestarian alam (terumbu karang) dan juga kurangnya ketersediaan fasilitas untuk pengawasan dari pemerintah. Untuk mengatasi hambatan-hambatan dalam pemanfaatan sumber daya alam berupa terumbu karang tersebut maka diperlukan inovasi paradigma yang baru baik dari pemerintah, pengusaha maupun rakyat sehingga dengan inovasi paradigma yang baru maka pemerintah akan lebih serius mengatasi permasalahan yang ada sekarang ini dengan menghapus kebijakan atau 
peraturan pemerintah yang lama yang dapat merugikan rakyat dalam mengembangkan sumber daya alamnya dengan mengeluarkan kebijakan-kebijakan pemerintah yang baru yang jelas dan bermanfaat bagi pemanfaatan sumber daya alam sehingga menjadi lebih maksimal dan bernilai tambah dan lebih, juga diperlukan pengawasan untuk setiap kebijakan-kebijakan pemerintah yang dikeluarkan karena dengan pengawasan maka dapat menghindari terjadinya penyimpanganpenyimpangan kebijakan yang dilakukan oleh oknum-oknum tertentu karena keserakahan pribadi sehingga kegiatan inovasi pengelolaan terumbu karang (Coral Governance) dapat mencapai sasaran bagi kesejahteraan rakyat.

Jadi aspek yang akan di inovasikan oleh pemerintah daerah adalah terumbu karangnya/ tata kelola terumbu karang (Coral Governance), karena terumbu karang tersebut telah mengalami degradasi (kerusakan) yang dilakukan oleh pihak-pihak yang tidak bertanggung jawab dalam rangka potensi terumbu karang tersebut dapat dijadikan sebagai penghasil dan nilai ekonomi bagi kesejahteraan masyarakat. Kemudian dengan disahkannya UU Nomor 32 Tahun 2004, maka kesempatan pemerintah lokal untuk memperoleh hak dalam mengelola sumberdaya alam yang terdapat di wilayahnya, dalam hal ini sumberdaya terumbu karang semakin besar. Namun harus disadari pula bahwa pengelolaan yang dilakukan oleh masyarakat lokal (pemda) selain memberikan peluang juga menuntut adanya tanggung jawab dari masyarakat tersebut.

Kewajiban atau tanggung jawab tersebut mempunyai arti bahwa masyarakat harus dapat turut memikul beban biaya yang diperlukan untuk memulihkan kembali sumberdaya tersebut agar tetap lestari. Biaya pengelolaan yang harus dipikul tersebut dapat meliputi berbagai hal seperti; penyediaan infrastruktur pengelolaan, pelaksanaan penegakan hukum, pemantauan kualitas sumberdaya, pengurangan unit-unit penangkapan ikan, pengurangan daerahdaerah penangkapan ikan, berkurangnya pendapatan dalam waktu tertentu, bantuanbantuan teknis, administrasi, penciptaan berbagai alternatif mata pencaharian, dan lain sebagainya.

Terkait dengan permasalahan diatas, untuk dapat mengoptimalkan hal tersebut serta mengembalikan fungsi-fungsi dan berbagai manfaat lain dari ekosistem terumbu karang sebagaimana di uraikan diatas, maka perlu upaya-upaya kreativitas dan inovasi yang akan dilakukan oleh pemerintah daerah misal membuat inovasi teknologi baru, lahirnya kebijakan baru, adanya gagasan-gagasan baru yang bersifat konstruktif dan hal-hal yang dapat membangun lainnya untuk menopang pengelolaan terumbu karang dalam bentuk tata kelola terumbu karang (coral governance) yang terpadu dan berkelanjutan yang berbasiskan pada pengelolaan masyarakat setempat.

Sehubungan dengan hal tersebut diatas, penulis kemudian terdorong untuk melakukan penelitian mengenai "Inovasi Pengelolaan Terumbu Karang (Studi Kasus Tentang Coral Governance) di Kabupaten Wakatobi". Adapun tujuan dari penelitian ini adalah untuk mengetahui inovasi pengelolaan terumbu karang (studi kasus tentang coral governance) di Kabupaten Wakatobi dan untuk mengetahui faktorfaktor yang dapat mendukung dan menghambat dalam inovasi pengelolaan terumbu karang di Kabupaten Wakatobi.

Kemudian manfaat penelitian ini diharapkan bermanfaat secara teoritis, yaitu sebagai bahan literatur atau hasil penelitian ini diharapkan dapat menambah bacaan dan memperluas wawasan keilmuan, khususnya dalam kajian ilmu pemerintahan. Manfaat secara praktis, yaitu sebagai bahan informasi atau menjadi bahan masukan bagi pemerintah daerah mengenai inovasi pengelolaan terumbu karang di Kabupaten Wakatobi.

\section{B. KONSEP TATA KELOLA}

Pengelolaan berasal dari kata manajemen atau administrasi. Managemen diterjemahkan dalam bahasa Indonesia menjadi manajemen atau pengelolaan. Dalam beberapa konteks keduanya mempunyai persamaan arti, dengan kandungan makna to control yang artinya mengatur dan mengurus. Menurut Manullang (2005) manajemen merupakan sebuah seni dan ilmu perencanaan, pengorganisasian, penyusunan, 
pengarahan, dan pengawasan sumber daya untuk mencapai tujuan yang sudah ditetapkan.

Terkait dengan proses pelaksanaan

manajemen, Nanang Fattah (2004:1) mengemukakan bahwa dalam proses manajemen terlihat fungsi-fungsi pokok yang ditampilkan oleh seorang manajer/pimpinan, yaitu : perencanaan (planning), pengorganisasian (organizing), pemimpinan (leading), dan pengawasan (controlling). Oleh karena itu, manajemen diartikan sebagai proses merencanakan, mengorganisasi, memimpin, dan mengendalikan upaya organisasi dengan segala aspeknya agar tujuan organisasi tercapai secara efektif dan efisien.

Dari beberapa pendapat tentang definisi yang telah dikemukakan, dapat disimpulkan bahwa pada dasarnya pengelolaan atau manajemen adalah suatu proses kegiatan perencanaan, pengorganisasian, penyusunan, pengarahan, pengendalian, serta pengawasan terhadap penggunaan sumber daya organisasi baik sumber daya manusia, sarana prasarana, sumber dana maupun sumberdaya lainnya untuk mencapai tujuan organisasi yang telah ditetapkan secara efektif dan efisien.

\section{KONSEP TERUMBU KARANG}

Terumbu karang merupakan kelompok organisme yang hidup di dasar perairan laut dangkal, terutama di daerah tropis. Meskipun karang ditemukan hampir di seluruh dunia, baik di perairan kutub maupun perairan ugahari, tetapi hanya di daerah tropik terumbu dapat berkembang. Karenanya pembentukan terumbu karang digunakan untuk membatasi lingkungan lautan tropik. (Kordi, 2010: 6).

Terumbu karang mempunyai beberapa manfaat, diantaranya yaitu: sebagai tempat hidupnya ikan-ikan yang banyak dibutuhkan manusia untuk pangan, seperti ikan kerapu, ikan baronang, ikan ekor kuning, dan lain-lain. Sebagai benteng pelindung pantai dari kerusakan yang disebabkan oleh gelombang atau ombak laut. Sebagai tempat untuk berwisata. (Iyam, 2007: 20).

Ancaman Terumbu Karang, ancaman yang bersifat antropogenik (disebabkan oleh manusia) yaitu sebagai berikut: Kemiskinan dan peningkatan populasi manusia., kegiatan konstruksi dan pengerukan, polusi air dan pembuangan sampah, penangkapan ikan yang berlebihan, penangkapan ikan menggunakan bom (bahan peledak). Ancaman dari alam. (Gunawan, dkk. 2006: 49-50).

\section{DESENTRALISASI PENGELOLAAN DAN PESISIR PADA ASPEK CORAL GOVERNANCE}

Kooiman et.al (2005) mendefenisikan tata kelola (governance) sebagai keseluruhan interaksi antara sektor publik dan sektor privat untuk memecahkan persoalan publik (societal problems) dan menciptakan kesempatan sosial (social opportunities). Tata kelola sumberdaya tidak dapat dilepaskan dari filosofis keterkaitan antara ekosistem, sumberdaya dan manusia yang terkait dengan pemanfaatan dan pengelolaan sumberdaya itu sendiri.

Desentralisasi adalah penyerahan urusan pemerintahan oleh pemerintah pusat kepada daerah otonom berdasarkan asas otonomi. Asas otonomi adalah prinsip dasar penyelenggaraan pemerintahan daerah berdasarkan otonomi daerah. Sedangkan Otonomi Daerah adalah hak, wewenang, dan kewajiban daerah otonom untuk mengatur dan mengurus sendiri urusan pemerintahan dan kepentingan masyarakat setempat dalam sistem Negara Kesatuan Republik Indonesia.

Pengelolaan wilayah pesisir (PWP) Di berlakukanya UU No. 27 Tahun 2007 Tentang Pengeloaan Wilayah Pesisir. Sebagaimana tercantum dalam pasal 1 ayat 1 yaitu dibawah ini sebagai berikut: pengelolaan wilayah pesisir dan pulaupulau kecil adalah suatu pengoordinasian perencanaan, pemanfaatan, pengawasan, dan pengendalian sumber daya pesisir dan pulau-pulau kecil yang dilakukan oleh Pemerintah dan pemerintah daerah, antarsektor, antara ekosistem darat dan laut, serta antara ilmu pengetahuan dan manajemen untuk meningkatkan kesejahteraan rakyat. Governance (tata kelola) dalam konteks terumbu karang. Governance tata kelola dalam konteks terumbu karang yaitu: elemen kebijakan, strategi dan perencanaaan, aransemen, mekanisme kelembagaan, PerundangUndanga, informasi dan peningkatan 
Vol. II, No. 2, Oktober 2012

kesadaran publik, mekanisme pembiayaan berkelanjutan, dan peningkatan kapasitas.

\section{E. METODE PENELITIAN}

Tipe penelitian ini adalah penelitian deskriptif kualitatif yakni suatu bentuk penelitian yang bertujuan untuk memberikan gambaran umum berbagai macam data yang dikumpul dari lapangan secara objektif, sedangkan dasar penelitiannya adalah survei yakni tujuan dari penelitian deskriptif ini adalah menggambarkan mengenai situasisituasi atau kejadian-kejadian secara sistematis, faktual dan akurat mengenai faktafakta dari Inovasi Pengelolaan Terumbu Karang di Kabupaten Wakatobi.

Dalam teknik pengumpulan data dimana sumber data dalam penelitian ini diperoleh melalui observasi wawancara lansung. Informan sebagai data primer serta diperoleh melalui data skunder mencakup dokumendokumen resmi, buku-buku, hasil penelitian, serta dokumen yang berisi informasi penting yang berhubungan lansung dengan masalah yang diteliti, termasuk juga dokumentasi yang dianggap mendukung. Kemudian data tersebut dikumpul disusun secara jelas dan sistematis dengan berpedoman pada panduan perpustakaan.

Teknik analisis data dilakukan melalui tiga tahap yaitu: reduksi data, penyajian data dan penarikan kesimpulan. Setelah menganalisis data, peneliti harus memastikan apakah interpretasi dan temuan penelitian akurat, validasi temuan menurut Creswell berarti bahwa peneliti menentukan keakuratan dan kredibilitas temuan melalui beberapa strategi, antara lain member checking, tringulasi dan auditing.

\section{F. HASIL DAN PEMBAHASAN}

Disini peneliti dapat mengklarifikasikan dari hasil penelitian mengenai inovasi pengelolaan terumbu karang. Diantara beberapa indikator inovasi pengelolaan terumbu karang yang dilakukan oleh pemerintah daerah dalam hal ini dinas kelautan dan perikanan adalah sebagai berikut

\section{Keterlibatan Pemangku Kepentingan (Stakeholder)}

Pengelolaan terumbu karang pada dasarnya merupakan suatu proses pengontrolan tindakan manusia agar pemanfaatan sumberdaya alam dapat dilakukan secara bijaksana dengan mengindahkan kaidah pelestarian lingkungan. Pengelolaan tersebut dimana pemerintah dan masyarakat sama-sama diberdayakan sehingga tidak ada ketimpangan dimana hanya masyarakat saja yang diharapkan aktif tetapi pihak pemerintah juga harus proaktis dalam menunjang pengelolaan terumbu karang ini dan harus dilakukan secara terpadu oleh beberapa instansi terkait.

Pengelolaan disini meliputi berbagai dimensi seperti perencanaan, pengawasan, pelestarian serta pemanfaatan, juga melibatkan seluruh stakeholder yang dianggap penting dalam meningkatkan pengelolaan terumbu karang. Sebagaimana yang dikatakan oleh bid. usaha \& pemasaran dari coremap dinas kelautan dan perikanan yaitu:

"Stakeholder itu semua sewakatobi yg dianggap penting dan memang aktif. jadi Stakeholder kan adalah siapa saja baik dia personal, pribadi atau perorangan maupun kelompok, maupun dia pejabat atau dia lembaga punya sendiri yg memiliki kepentingan yg besar dan sama terhadap satu fokus dalam melakukan pengelolaan terumbu karang ini" (Wawancara ON).

Hasil wawancara saya dengan bapak ON diatas penulis dapat menyimpulkan bahwa keterlibatan seluruh stakeholder wakatobi adalah sangat aktif dan semua forum atau kelembagaan memiliki pandangan yang sama dan saling bersinergi untuk fokus dalam melakukan pengelolaan terumbu karang ini. Sebagaimana yang di kemukakan pula oleh kepala seksi konservasi dan tata ruang pesisir dari dinas kelautan dan perikanan yaitu :

"Ia Jadi kalau keterlibatan stakeholder sebenarnya lebih kepada kepengawasanya ya. kita coba stering duduk bersama untuk membicarakan model pengawasannya ini. kita bersama-sama seluruh elemen stakeholder yang intens bergerak 
dibidang konservasi. diantaranya ada namanya lembaga-lembaga lokal misalnya LSM lokal kaya diwangi-wangi yang namanya Komanangi (Komunitas Masyarakat Nelayan Wangi-Wangi), kalau di Kaledupa namanya Forkani (Forum Kaledupa Tandani), terus ada di Tomia namanya komunto (komunitas nelayan tomia) kemudian dibinongko namanya FORNEB (Forum Nelayan Binongko). kemudian dengan unsur Balai Taman Nasional Wakatobi (BTNW), unsur WWF (Word Wide Fordations), kemudian unsur toko-toko adatnya yaitu adat dari 4 pulau ini. Ini kami duduk bersama memformulasi sebuah yang kami istilahkan dengan protocol monitoring. Jadi diprotocol monitoring itu memuat misalnya panduan bagi tim yang tergabung dari beberapa elemen stakeholder tadi bagaimana dalam melakukan pengawasan, jadi disitu lengkap dan bagaimana kita turun, dari mana kita start, kemudian pada saat melakukan pengawasan itu kita bersikap seperti apa, kemudian siapa yang dianggap sebagai pimpinan disitu. Kemudian pada saat pelatihan kita juga libatkan stakeholder melalui perwakilannya". (Wawancara MJ).

Hasil wawancara saya dengan bapak MJ tersebut diatas dapat disimpulkan bahwa jelaslah ada keterlibatan stakeholder yang lebih mengarah kepada pengawasan dibidang konservasi ini bahwa seluruh LSM lokal maupun lembaga terkait seperti adat, taman nasional dan sebagainya adalah duduk berkumpul bersama untuk memformulasikan dengan istilah protokol monitoring yang memuat sebagai panduan bagi tim untuk membahas bagaimana persiapan yang harus dilakukan, siapa pemimpinya, start dan turun kemana arah mulainya untuk melakukan pengawasan ini. Dan terakhir termasuk juga melibatkan masing-masing perwakilan dari stakeholder LSM, pokmaswas, toko adat dari 4 pulau termasuk juga Taman Nasional, ikut aktif ketika ada program pelatihan-pelatihan yang diselenggarakan oleh Coremap dari pemerintah daerah dalam hal ini Dinas Kelautan dan Perikanan.

Disamping itu keterlibatan stakeholder dalam melakukan pengelolaan terumbu karang adalah melakukan transplantasi terumbu karang (pembibitan terumbu karang) yaitu membibit rumput karang baru untuk menanam didasar laut dengan menggunakan tegnologi baru berupa media cor, pasang aliran listrik dan sebagainya. Seperti yang dikatakan oleh Kepala Seksi Konservasi dan Tata Ruang Pesisir dari Dinas Kelautan dan Perikanan:

"Kalau untuk program khusus di kami ya disetiap konservasi kemarin sudah tiga tahun terakhir kita itu melati masyarakat memperkenalkan tentang bagaimana wujud terumbu karang ini bisa ditranplantasi dengan memakai media cor. Kemudian kemarin ditahun anggaran 2013 kami bekerja sama dengan Universitas Hasanudin (UNHAS) juga memperkenalkan metode transplantasi dengan istilah bairons yang secara sederhananya bahwa dia (masyarakat) mennggunakan arus listrik untuk mendorong tumbuhan karang ini" (wawancara MJ).

Hal ini senada dengan menurut RD selaku Bid. Pembangunan Perikanan sebagai staf di dinas kelautan dan perikanan Kabupaten Wakatobi mengatakan:

"Kalau pengembanganya disamping menjaga kita juga melakukan rehabilitasi pada daerah-daerah yang sudah rusak seperti melakukan transplantasi juga pernah kerjasama dengan UNHAS dengan metode bairons, jadi ada semacam rangka besi kmudian disimpan di Daerah-Daerah terumbu karang kemudian ada aliran listrik sehingga karang-karang cepat menempel kemudian tumbuh dan mengikuti bentuk rangkanya tadi" (Wawancara MJ).

Berdasarkan kedua hasil wawancara saya dengan bapak MJ dan RD tersebut di atas peneliti dapat menyimpulkan bahwa transplantasi terumbu karang merupakan salah satu teknik pelestarian (rehabilitas) terumbu karang yang semakin terdegradasi dengan teknik memakai media cor, bairons, rangka besi, juga menggunakan aliran listrik untuk mendorong pertumbuhan 
Vol. II, No. 2, Oktober 2012

karang. Jadi tranplantasi dilakukan untuk diperkenalkan dengan tujuan mempercepat regenerasi terumbu karang yang telah rusak atau untuk kembali membangun daerah terumbu karang yang baru yang sebelumnya tidak ada.

\section{Berdasarkan Pengetahuan Lokal Dan Moderen}

Tindakan pemerintah dalam hal membuat kebijakan mengenai pengelolaan terumbu karang ditingkat Nasional maupun Daerah tentunya berdasarkan kebiasaan dan pengetahuan masyarakat lokal itu sendiri agar pengelolaan tersebut dapat diterima dan melibatkan masyarakat untuk ikut berpartispatif dalam melakukan pengawasan, pelestarian dan pemanfaatan terumbu karang di kawasan wilayah daerah perlindungan laut atau wilayah taman nasional yang telah ditetapkan oleh aturan daerah maupun desa dan adat setempat. Sebagaimana yang diungkapkan oleh Bid. Usaha \& Pemasaran dari Coremap Dinas Kelautan dan Perikanan:

"Iya saya kira bahwa banyak bentukbentuk kearifan lokal atau lokal lindung yang harus digali dalam rupa penyelamatan terumbu karang dan melakukan pengelolaan lindung yang sesuai pengetahuan mereka yang mereka anut karena disana memiliki sebuah historis kepercayaan yang ditakuti dan juga memiliki nilai adat yang dimana aturanya bisa mengembangkan sistem tata kelola yang ada di daerah perlindungan laut. Sekarang paradigma berpikir masyarakat harus kita dorong atau kita rubah mainsetnya untuk bisa menghasilkan keuntungan atau uang yang lebih dari jasa lingkungan. Adapun pengetahuan modern di Coremap itu selalu bekerja sama dgn para ahli baik itu jasa tuntutan secara pribadi maupun bekerjasama dgn lembaga termasuk Universitas Haluholeo (UNHALU) Kendari utk memberikan motifasi dalam menyelamatkan terumbu karang terhadap nilai, nilai itu hanya bisa mampu orang cerdas, orang cerdas itu tempatnya adalah di Universitas dan Akademik itu harus paham juga bahwa di Wakatobi ini masih terbatas sumberdayanya" (Wawancara ON).
Hasil wawancara saya dengan bapak ON tersebut dapat disimpulkan bahwa tindakan pemerintah daerah dalam hal menerbitkan kebijakan pengelolaan terumbu karang adalah sangat sesuai dengan pengetahuan lokal yang tercantum dalam nilai-nilai kearifan lokal berupa adat yang memiliki sebuah kepercayaan terhadap cerita yang mereka takuti sehingga nilai tersebut dapat dikembangkan untuk dijadikan sebagai sistem tata kelola yang ada di daerah perlindungan laut, kemudian juga paradigma berpikir masyarakat yang mainsetnya dirubah dan didorong untuk bisa menghasilkan keuntungan dari jasa lingkungan tersebut. Termasuk juga pengetahuan modern yang dimana dalam program Coremap selalu bekerjasama dengan para ahli, kelembagaan termasuk juga Universitas Halu Oleo Kendari Sulawesi Tenggara dengan tujuan untuk memberikan motifasi dalam penyelamatan terhadap terumbu karang. Senada dengan penjelasan oleh kepala seksi konservasi \& tata ruang pesisir dari dinas kelautan dan perikanan bahwa :

"jadi kami sebenarnya mencoba memperkenalkan bahwa ternyata terumbu karang ini bisa ditumbuh kembangkan melalui konsep transplantasi tadi terus kemudian inovasi juga mungkin lebih banyak kemasyarakatnya atau kemanusiaan untuk menyelamatkan terumbu karang ini. Jadi manusiannya yang harus kita dekat yang harus kita arahkan supaya mereka itu mendapat pencerahan penyadaran dari tindakan pemerintah ini, sebenarnya kami beranggapan bahwa kerusakan terumbu karang ini bukan karena faktor alamnya tapi faktor manusiannya sehingga salah satu contoh merubahnya itu adalah secara rutin kita memberikan penyuluhan kepada mereka" (Wawancara, MJ).

Berdasarkan hasil wawancara tersebut diatas penulis dapat menyimpulkan bahwa salah satu tindakan pemerintah yang diperkenalkan adalah melalui tranplantasi kemudian juga 
melakukan pencerahan dan penyadaran akan pentingnya penyelamatan terumbu karang karena pemerintah beranggapan bahwa terjadinya kerusakan bukan saja karena faktor alamnya tetapi juga karena faktor manusianya sehingga salah satu contoh untuk merubahnya adalah melakukan penyuluhan secara rutin kepada mereka (masyarakat) dalam rangka memberikan penyadaran/ pencerahan. Statemen tersebut dapat di dukung oleh kedua tokoh Masyarakat Nelayan Desa Mola Selatan Kecamatan Wanci Kabupaten Wakatobi yang mengatakan bahwa:

"ya sesuai karena kami pernah dipanggil oleh pemerintah jadi kami tahu tentang apa yg boleh dn tidak boleh serta kesesuaian keinginan dan pelarangan terhadap pelestarian terumbu karang" (Wawancara, DL).

Lebih lanjut GS sebagai Masyarakat Nelayan juga mengatakan:

"Iya sangat sesuai dengan pengetahuan masyarakat karena kami tauh dan ingin melestarikan terumbu karang juga kami sepakat dengan pemerintah melarang pemboman, pembiusan karena kami tidak ingin terumbu karang ini hancur dikarenakan bom karena mata pencaharian kami adalah nelayan to" (Wawancara GS).

Kedua hasil wawancara saya dengan Masyarakat Nelayan yang bernama bapak DL \& GS tersebut diatas peneliti dapat menyimpulkan bahwa masyarakat dapat menghadiri panggilan dari Pemerintah melalui pertemuan berupa pelatihan dan sosialisasi untuk membahas mufakat dalam melestarikan karang dan mencegah hal-hal yang dapat merusak terumbu karang seperti bom, bius dan lain sebagainya sehingga ternyata pengetahuan masyarakat sangat koherensi dengan tindakan pemerintah karena sebagian besar mata pencaharian masyarakat adalah nelayan dan mereka juga tidak ingin terumbu karang ini rusak akibat pemboman, pembiusan, dan lain sebagainya. Seperti yang dikemukakan pulah oleh informan LA selaku Kasi. Bina Usaha \& Kelembagaan dari Coremap Dinas Kelautan dan Perikanan berikut dibawah ini:

$$
\begin{aligned}
& \text { "Iya intinya disitu antara masyarakat } \\
& \text { adat stakeholder dengan pemerintah }
\end{aligned}
$$

daerah itu berdiri bersama-sama menyusunnya ransemen rencana pengelolaan terumbu karang sehingga kawasan itu mau dijadikan apa dan nilai ekonomi bagi masyarakat sehingga itu yang diputuskan bersama untuk inovasi pengembangannya seperti apakah pengembangan ekosistem wisata bahari atau desa wisata atau desa adat atau kawasan konservasi bangkitkan terus seperti pemukiman dan semua itu berdasarkan kesepakatan antara pemerintah daerah, sehingga pemerintah daerah mendorong itu, mendorong kelompok itu, mendorong kelembagaan itu untuk mengembangkan dalam hal teknologi seperti itu. (Wawancara, LA).

Hasil wawancara tersebut diatas dapat disimpulkan bahwa inti pertemuan diberbagai kelembagaan masyarakat dan pemerintah bersama-sama menyusun ransemen pengelolaan untuk mengembangkan terumbu karang agar menjadi nilai ekonomi bagi kesejahteraan masyarakat sehingga dengan demikian pemerintah membangkitkan semangat pengetahuan mereka dan mendorong kelompok serta kelembagaan yang ada di masyarakat.

Berikutnya bahwa tindakan pemerintah daerah dalam melakukan pengelolaan terumbu karang adalah pengelolaan yang berbasiskan pada masyarakat itu sendiri yaitu dari masyarakat oleh masyarakat dan untuk masyarakat. Sebagaimana yang dilansir oleh kasi. bina usaha \& kelembagaan dari coremap dinas kelautan dan perikanan ia mengatakan bahwa:

Iya, bahwa pengembangan pengelolaan terumbu karang adalah pengembangan sistem pengawasan berbasis masyarakat yang dilakukan dari masyarakat oleh masyarakat dan untuk masyarakat sehingga mereka itu ada sebuah singkronisasi antara pokwasmas, lembaga dengan dinas kelautan dan perikanan sebagai instansi tehnik untuk melakukan pengembangan konservasi. (Wawancara LA). 
Vol. II, No. 2, Oktober 2012

Hasil wawancara saya dengan bapak LA tersebut dapat disimpulkan bahwa tindakan pemerintah daerah dalam melakukan pengelolaan terumbu karang adalah pengelolaan yang berbasiskan pada masyarakat oleh masyarakat dan untuk masyarakat. Pengelolaan yang berbasis pada masyarakat ini merupakan salah satu konsep program dari Coremap dalam rangka upaya pelestarian terumbu karang yang ada pada kawasan daerah-daerah perlindungan laut disetiap lokasi coremap.

Terkahir mengenai hal-hal pengelolaan terumbu karang yang dilakukan oleh pemerintah daerah adalah Pemberdayaan masyarakat melalui pencaharian alternatif yaitu mengalihkan kegiatan masyarakat dari yang merusak menjadi yang produktif. Sebagaimana yang di paparkkan oleh Kasi. Bina Usaha \& Kelembagaan dari Coremap Dinas Kelautan dan Perikanan bahwa:

strategi yang digunakan oleh pemerintah daerah adalah dalam hal ini dinas kelautan dan perikanan itu adalah bagaimana memberdayakan mereka melalui pengembangan mata pencaharian alternatif masyarakat itu bahwa bisa mengalihkan kegiatan mereka dari yang merusak menjadi yang produktif. (Wawancara LA, 31 Juli 2015).

Berdasarkan hasil wawancara saya dengan informan LA tersebut diatas penulis dapat menyimpulkan bahwa kegiatan untuk memberdayakan masyarakat adalah melalui pengembangan mata pencaharian alternatif yaitu mengalihkan tenaganya dari yang merusak menjadi yang produktif kemudian juga dari penggunaan alat tangkap yang dapat merusak lingkungan menjadi ramah lingkungan. Jadi pemberdayan tersebut merupakan salah satu strategi yang dilakukan oleh Pemerintah Daerah dalam hal ini Dinas Kelautan dan Perikanan dengan tujuan memberikan penyadaran dan pengetahuan akan pentingnya pelestarian dan penjagaan serta dapat memproduksikan terumbu karang untuk nilai pertumbuhan ekonominya.

\section{Ada Kendali Terhadap Segenap Aktifitas}

Pada tahap pengendalian yang dilakukan oleh para segenap aktifitas untuk terus aktif dan mengefektivitaskan pengelolaan tersebut sehingga terumbu karang tetap lestari, dilindungi, dirawat, diawasi dan pemanfaatan terumbu karang untuk kesejahteraan masyarakat. oleh karena itu program coremap lebih banyak kekonteks pengelolaan yang berbasis masyarakat. Artinya masyarakat bisa melakukan pengendalian untuk memonitoring serta melakukan patroli atau memantau pada kawasan wilayah daerah perlindungan laut. Sebagaimana yang dijelaskan oleh informan LA selaku kasi. bina usaha \& kelembagaan dari coremap dinas kelautan dan perikanan berikut dibawah ini:

"Iya sistem pengawasannya berbasis masyarakat sehingga kita itu memonitoring semua melalui pengendalian kita secara terinci di dinas kelauatan dan perikanan (DKP), kemudian dgn stakeholder terus instansi tehnik seperti balai taman nasional pol airit dan polres itu semua bersinergi yang kita bentuk dalam tim pengawasan terpadu kabupaten, itu masuk dalam fungsional dipengawasan terpadu beserta pengendalianpengendaliannya. kemudian sebenarnya di coremap kita lebih banyak kekonteks berbasis masyarakatnya tapi kalau untuk pengawasan itu ada di instansi pengawasan dilakukan secara rutin satu tiga atau empat dalam satu bulan juga rutin secara bulanan terpadu, ada juga pengawasan yang tidak terduga pada adat yang terkadang ada informasi yang misal darurat itu kita komunikasi secepatnya dengan komunitas tehnik tersebut. (Wawancara, LA).

Berdasarkan Wawancara diatas peneliti dapat mendeskripsikan bahwa pengelolaan tersebut dapat dimonitoring melalui pengendalian oleh dinas kelautan dan perikanan juga dapat menfungsikan pengawasan secara rutin dalam satu bulan yang mungkin 3-4 kali yang diantaranya melibatkan seluruh instansi yang terkait dan mereka juga saling komunikasi dan bersinergi dalam memberikan informasi terhadap kasus hal-hal yang dapat merusak terumbu karang maupun hal-hal yang bersifat darurat lainya.

Kemudian, pemerintah daerah juga membentuk kelompok masyarakat pengawas ditingkat tiap desa yang 
fungsinya adalah melakukan pengawasan di daerah-daerah pesisir khususnya di kawasan daerah perlindungan laut. Sebagaimana yang dikemukakan oleh Kepala Seksi Konservasi dan Tata Ruang Pesisir Dinas Kelautan dan Perikanan:

"kita ini juga sudah membina kelompokkelompok masyarakat dalam bentuk POKMASWAS (Kelompok Masyarakat Pengawas) itu sudah ada di 63 desa. Ini arahnya bagaimana kami mendorong masyarakat yang terikut dalam pokmaswas ini untuk bekerja secara mandiri. Jadi kami tingkatkan kesadarannya bahwa memang sebenarnya terumbu karang ini adalah milik masyarakat dimanfaatkan oleh masyarakat dan menjaganya juga harusnya masyarakat, itu yang kami dorong supaya mereka betul-betul sadar bahwa terumbu karang ini sangat penting untuk dijaga dan dilestarikan karena mereka juga kan mencarinya disitu. (Wawancara, MJ).

Hal ini senada seperti yang dilansir oleh RD selaku Bid. Pembangunan Perikanan sebagai staf dari dinas kelautan dan perikanan mengatakan bahwa:

"Inovasi pengelolaan terumbu karang adalah tidak lebih kepada konservasi untuk menjaga terumbu karang supaya tidak dirusak dalam rangka itu inovasi pemerintah kabupaten wakatobi adalah melibatkan masyarakat yang biasa disebut namanya membentuk pokmaswas. Pokmaswas itu singkatan dari kelompok masyarakat pengawas jadi masyarakat yang mengawasi terumbu karang yang ada di desanya masing-masing. (Wawancara, RD).

Hasil dari kedua wawancara saya dengan MJ \& RD tersebut diatas keduanya dapat disimpulkan bahwa pemerintah daerah dalam hal ini dinas kelautan dan perikanan (dkp) telah membentuk kelompok masyarakat yang namanya pokmaswas dan pokmaswas ini sudah tersebar di 63 desa dengan tujuan dibentuknya kelompok ini adalah agar masyarakat dapat menjaga, mengawasi, melestarikan dan memanfaatkan terumbu karang yang ada di desanya masing-masing.

\section{Alokasi Sumberdaya}

Komponen sumberdaya berupa alam, manusia dan dana adalah salah satu masukan (input) penting dalam penerapan pengelolaan terumbu karang yang secara konprehensif di Kabupaten Wakatobi sehingga kegiatan-kegiatan seperti pelatihan, pengawasan, pelestarian dapat aktif dilakukan oleh seluruh stakeholder baik dari masyarakat dan pemerintah maupun instansi terkait lainya. Untuk alokasi sumberdaya berupa dana (anggaran) baik dari APBN (pusat) maupun dari APBD (daerah) dapat mengalokasikan kepada kegiatan-kegiatan yang dapat menopang pengelolaan terumbu karang. Sebagaimana yang diungkapkan oleh Bid. Usaha \& Pemasaran dari Coremap Dinas Kelautan dan Perikanan mengatakan:

Ok untuk pemerintah daerah tentu untuk melakukan pengawasan baik itu pokmaswas maupun dari kegiatan patroli dan sebagainya itu membutuhkan dana yg dilepaskn kesitu yang kedua juga sarana dan prasarana pendukung seperti bodi pengawasan dan yang terpenting lagi adalah membangun sistem kelembagaan karena wilayah laut kita sangat luas semuanya taman nasional orang bisa masuk kemana-kemana dari segala arah dan wilayah laut kita juga adalah taman property siapa saja bisa masuk maka sistem yang harus dibuatkan pemerintah tidaklah cukup baik politik dan sebagainya itu melakukan sebuah pengembangan kawasan kalau tidak melibatkan masyarakat secara swadaya untuk mengambil peran aktif dan melakukan fungsi-fungsi pengawasan secara efektif. (Wawancara ON, 01 Agustus 2015).

Hasil wawancara saya dengan informan ON tersebut dapat disimpulkan bahwa alokasi sumberdaya berupa dana dianggarkan kepada kegiatan-kegiatan operasi patrroli dan pengawasan yang dilakukan oleh seluruh stakeholder baik pemerintah, LSM, pokmaswas maupun kelompok lainya serta memfasilitasi sarana dan prasarana berupa bodi pengawas termasuk juga masyarakat nelayan diberi 
Vol. II, No. 2, Oktober 2012

bantuan berupa bodi/ ketinting dan sebagainya. Kemudian dana tersebut dialokasikan juga kepada seluruh lembaga yang intes melakukan fungsi-fungsi pengawasan secara efektif. Hal ini dapat didukung oleh Masyarakat Nelayan di desa Mola Selatan dan lsm forum aspirasi masyarakat pesisir di Desa Liya Togo diantaranya dari LSM (FAMP) mengatakan:

"Iya ada bantuan dari anggota DPRD juga pemerintah daerah untuk tranplantasi terumbu karang, dana tersebut juga kita gunakan untuk biaya transportasi darat dan laut serta bantuan semacam tali, rombong ini fungsinya untuk menangkap ikan tuna". (Wawancara, AW).

Begitu juga pemaparan dari Masyarakat Nelayan dari Desa Mola Selatan mengatakan bahwa:

"Iya kami masyarakat nelayan yang saya dengar itu ada bantuan dana PNPM yang katanya itu dana bergilir berupa ketinting (bodi), jaring maupun bantuan lainya tapi hanya sebagian tertentu saja dan tidak semua yang dapat itu. Adapun kegiatankegiatan pengawasan yang dilakukan oleh kapal-kapal putih itu kami sering lihat yang mereka memantau di laut terus kami pernah didatangi ditanyain dan menasehati kami mengenai ini yang boleh dan ini yang tidak boleh gitu". (Wawancara, DL).

Berdasarkan hasil wawancara saya dengan lembaga LSM FAMP maupun masyarakat nelayan yang kesemuanya penulis dapat menyimpulkan bahwa ternyata anggaran pernah dialokasikan kepada lembaga LSM FAMP serta Masyarakat Nelayan yang kemudian bantuan tersebut mereka menggunakanya untuk pengelolaan terumbu karang berupa transplantasi maupun untuk biaya transportasi laut dan darat bagi LSM (FAMP), begitu juga masyarakat nelayan menggunakan bantuan tersebut untuk nelayan/ nangkap ikan sekaligus ikut mengawasi kawasan laut yang apa bila melihat ada hal-hal yang mencurigakan seperti pemboman, pembiusan serta masuknya pendatang dari luar daerah yag datang untuk menangkap ikan dengan cara illegal fishing sehingga dengan demikian mereka segera lansung menginformasikan kepada Pemerintah Dinas Kelautan dan Perikanan.

\section{Pilihan dan Tujuan Publik/ Masyarakat}

Kebijakan Pemerintah Daerah Kabupaten Wakatobi sebagaimana tercantum dalam visi Perda No. 3 Tahun 2013 tentang Rencana Pembangunan Jangka Menengah Daerah (RPJMD) yaitu "Terwujudnya Surga Nyata Bawah Laut di Pusat Segitiga Karang Dunia". Adalah yang nilainya bersumber dari budaya lokal, pilihan dan tujuan masyarakat itu sendiri bahkan segala tindakan dan aturan pemerintah tentunya berdasarkan pilihan dan tujuan publik sehingga tindakan dan aturan tersebut dapat diterima dan dilaksanakan oleh masyarakat setempat. Sebagaimana yang dikatakan oleh bid. usaha \& pemasaran dari coremap dinas kelautan dan perikanan yaitu:

"Saya kira visi misi pemerintah daerah adalah mewujudkan surga nyata bawa laut dijantung segitiga karang dunia. Kemudian muara basis dan modal itu ada pada sektor kelautan dan perikanan, makanya sektor kelautan perikanan dan pariwisata itu dijadikan sebagai sektor unggulan didaerah ini. Nah untuk mewujudkan itu saya kira koordinasi lintas stakeholder termasuk institusi harus dibangun untuk bisa mendukung bagaimana upaya pelestarian sumberdaya kelautan dan perikanan termasuk terumbu karangnya. jadi pilihan itu sangat tepat tidak mengada-ngada karena itu juga di dukung oleh sumberdaya lokal dan fakta-fakta lapangan yang sudah tercantum kedalam sistem. (Wawancara ON).

Berdasarkan hasil wawancara saya dengan bapak ON tersebut dapat disimpulkan bahwa memang pilihan dan tujuan publik telah tercantum dalam visi misi karena di dukung oleh budaya kearifan lokal termasuk sistem yang ada sehingga koordinasi lintas stakeholder dan seluruh institusi dapat dibangun dan saling 
bersinergi dalam upaya pelestarian pengelolaan terumbu karang di Kabupaten Wakatobi.

\section{Ada Otoritas Pengelolaan}

Pemerintah juga bisa membuat kebijakan baru yang tidak bertentangan dengan perundang-undangan dari pusat yang tersebut diatas berupa Perda, Perdes bahkan aturan adat yang ada di masyarakat untuk dijadikan sebagai pedoman agar pihak sipengelola memiliki otoritas dalam melakukan pengelolaan terumbu karang pada kawasan wilayah konservasi yang telah ditetapkan oleh adanya berbagai aturan tersebut seperti penetapan luas zona dan lain sebagainya. Sebagaimana yang dikemukakan oleh informan SD selaku kasi. perikanan tangkap sebagai staf dinas kelautan dan perikanan bahwa:

"Iya yang sudah ada sekarang itu adalah ditingkat desa yang namanya perdes peraturan desa tentang DPL yang di program oleh coremap atau surat/kebijakan bupati tentang DPL. Kemudan UU yang kita berpedoman itu pada UU perikanan, UU tentang pesisir No. 27 tahun 2007 tentang PWP dan pulau-pulau kecil. Adapun ditingkat desa mungkin selain aturan, kita lihat juga peraturan yg tidak tertulis yg mereka sepakati sendiri. Misalnya seperti di pulau runduma itu ada larangan untuk mengambil telur penyu nah itu yang mereka sepakati dan memang secara nasional dilarang jadi bagi mereka kapan ketika disitu ada hasil baru ada larangan dan ada sanksinya" (Wawancara, SD).

Hasil wawancara saya dengan Bapak SD tersebut diatas penulis dapat menyimpulkan bahwa otoritas yang mereka miliki dalam melakukan pengelolaan terumbu karang adalah telah mengacu kepada UU yang telah ada dari Pusat maupun Peraturan Menteri Kelautan dan Perikanan serta kebijakan pemerintah daerah maupun peraturan adat dan aturan yang secara tidak tertulis yang mereka sepakati sehingga dengan keberadaan aturan tersebut menjadi payung otoritas dan memiliki kewenangan bagi sipengelola dalam melakukan pengelolaan terumbu karang pada kawasan yang telah ditetapkan dalam aturan seperti lokasi daerah perlindungan laut maupun wilayah taman nasional lainya.

Selain mengacu kepada aturan pusat pemerintah daerah juga menetapkan aturan perdes yang telah dibentuk dalam rangka menopang pengelolaan terumbu karang ditiap desa agar mereka memiliki otoritas dalam melakukan pengelolaan terumbu karang di wilayahnya masing-masing. Sebagaimana yang di kemukakan oleh beberapa informan Menurut SD selaku Kasi. Perikanan Tangkap sebagai Staf dari Dinas Kelautan dan Perikanan mengatakan:

"Iya, yang sudah ada sekarang itu adalah ditingkat desa yang namanya Peraturan Desa (Perdes) tentang DPL (Daerah Perlindungan Laut) pada waktu program Coremap. Jadi semua desa-desa dicoremap itu mereka membentuk peraturan desa tentang DPL atau surat Bupati tentang DPL. Cuman sekarang pelaksanaanya itu, sebenarnya di Perdes itu hanya mengatur ya, kalaupun ada larangan itu sudah sifatnya umum yang namanya membius membom itu memang tuntutan perdes itu dilarang". (Wawancara, SD).

Menurut AL dari LSM Setia Karang Mandati satu Kecamatan Wangi-Wangi Selatan Kababupaten Wakatobi ia mangatakan bahwa:

"Untuk penetapan lokasi daerah lindung dimasing-masing desa adalah merujuk pada aturan permen yang turun dari pusat atau perda sehingga kemudian aturan yang muncul dari desa ini tidak bertumpang tindis dengan perda yang ada dari kabupaten". (Wawancara, AL).

Menurut LA selaku kasi. bina usaha dan kelembagaan dari coremap dinas kelautan dan perikanan, berikut argumennya ia mengatakan:

"kalau yang memperkuat masyarakat itu adalah kelembagaan desa hukum adat termasuk kearivan lokal terus peraturan desa yang melekat didesa itu sendiri. Peraturan desa yg secara tertulis seperti intinya didalam itu menyangkut luas kawasan konservasi kemudian sanksi hukuman dan semuanya itu. Sanksi bagi orang yg melanggar". (Wawancara, LA). 
Vol. II, No. 2, Oktober 2012

Ketiga argumen dari hasil wawancara tersebut diatas peneliti dapat menyimpulkan bahwa di masing-masing Desa telah memiliki aturan Desa yang bernama Perdes. Perdes ini adalah aturan yang secara tertulis dan tidak bertumpang tindis atau kontrakdiksi dengan aturan dari Permen/Pemda, dan juga aturan tersebut mengatur pada wilayah kawasan Daerah Perlindungan Laut, kemudian juga di berlakukan sebagai acuan dalam melakukan peningkatan pengelolaan terumbu karang melalui pengawasan serta memberi hukuman atau sanksi bagi yang melanggar terhadap aturan-aturan yang sudah ditetapkan di Perdes itu sendiri.

\section{Faktor Pendukung Dan Penghambat}

Faktor pendukung Pemerintah Daerah dalam melakukan inovasi pengelolaan terumbu karang di Kabupaten Wakatobi adalah hal-hal yang dapat mendukung keberhasilan Pemerintah Daerah dalam meningkatkan penglolaan terumbu karang pada kawasan daerah yang telah di konservasi berupa DPL, wilayah Taman Nasional maupun zona-zona yang telah ditetapkan oleh aturan sebagaimana yang di ungkapkan oleh Kepala Seksi Konservasi \& Tata Ruang Pesisir dari Dinas Kelautan dan Perikanan yaitu:

"kalau bicara faktor pendukung jelaslah pasti yang pertama itu anggaran yang kedua sumberdaya baik kami disini pengelola stakeholdernya kemudian dukungan dari nelayan juga penting. Artinya apa yang kami berasumsi bahwa kalau ketiga elemen ini bersatu kemudian memiliki konsep yang jelas ini tentu sangat mendukung dan akan menjadi kekuatan Sehingga kegiatan pengelolaan terumbu karang ini menjadi aktif karena arahnya kesitu. Jadi adanya sinergi dari beberapa elemen dari stakeholder baik pemerintahnya kemudian LSM-nya, kemudian masyarakat dan lainya" (Wawancara, MJ).

Berdasarkan hasil wawancara saya dengan bapak MJ tersebut dapat disimpulkan bahwa faktor-faktor yang dapat mendukung Pemerintah Daerah dalam hal ini Dinas Kelautan dan Perikanan adalah terdapatnya sinergisitas dan dukungan dari beberapa elemen stakeholder baik stakeholder dari
Pemerintah, LSM, Masyarakat Adat dan Masyarakat Nelayan. Dengan demikian kegiatan pengelolaan terumbu karang menjadi terus aktif dan berkelanjutan.

Adapun hambatan-hambatan dalam inovasi pengelolaan terumbu karang adalah hal-hal yang dapat menghambat kinerja pemerintah daerah dalam meningkatkan pengelolaan terumbu karang sebagaimana yang dikatakan oleh kepala seksi konservasi \& tata ruang pesisir dari dinas kelautan dan perikanan yaitu:

"ya hambatanya adalah sebenarnya kami menemui kebiasaan cara-cara menangkap yang masih menggunakan alat-alat merusak dan kami harus akui bahwa itu masih ada jadi ini juga termasuk menghambat kemudian kesadaran masyarakat kita perlu masih ditingkatkan lagi begitu. (Wawancara, MJ).

Wawancara saya dengan bapak MJ tersebut diatas dapat disimpulkan bahwa masih adanya kebiasaan-kebiasaan dengan menggunakan alat-alat yang dapat merusak terumbu karang juga kurangnya kesadaran masyarakat dalam memahami akan pentingnya pelestarian terumbu karang sehingga pelaksanaan inovasi pengelolaan yang di programkan oleh Coremap di Dinas Kelautan dan Perikanan masih kurang efektif/belum semaksimal dalam meningkatkan inovasi pengelolaan terumbu karang.

Kebijakan keberlanjutan pengelolaan terumbu karang sangat diperlukan mengingat adanya dua kepentingan utama, yakni adanya kebutuhan untuk melindungi dan melestarikan terumbu karang serta kebutuhan untuk mengelola terumbu karang secara rasional, mengatasi konflik pemanfaatan dan mencapai keseimbangan antara pemanfaatan dan pelestarian maka Pemerintah Daerah menetapkan prioritas pembangunan Wakatobi tahun 2014.

Sebagai komitmen jangka panjang untuk pengelolaan sumber daya terumbu karang dan ekosistem terkait lainnya maka Pemerintah Daerah mengimplementasikan Program Rehabilitasi (COREMAP) dan Pengelolaan Terumbu Karang secara berkelanjutan bahwa Prioritas pembagunan Kabupaten Wakatobi tahun 2014 merupakan lanjutan dari prioritas yang 
telah ditetapkan dalam RPJMD Kabupaten Wakatobi Tahun 2006-2011. Sebagaimana yang dikatakan oleh Bid. Usaha \& Pemasaran dari Coremap Dinas Kelautan dan Perikanan mengatakan:

Saya kira bicara rencana pembangunan untk mendukung itu telah dituangkan dalam RPJMD (rencana pembangunan jangka menengah daerah). Didalam RPJMD tertulis bagaimana untuk mewujudkan visi dan misi kita itu tadi, harus ada dilakukan pro pendekatanya adalah program-programnya, sasaransasarannya, kegiatanya seperti apa untuk bisa mewujudkan itu dan itu, itu akan tertuang didalam rencana tahunan masing-masing dinas terkait. Jadi itu direncanakan, jadi pemerintah daerah mewujudkan dan menetapkan visimisinya juga itu tertulis RPJMD. RPJMD itu akan digambarkan dalam renstra atau rencana strategi dinas kelautan dan perikanan, dinas pariwisata dan lain sebagainya untuk mewujudkan itu. Jadi pengelolaan terumbu karang yang berkelanjutan ini merupakan harga mati karena visi pemerintah daerah itu ada disumberdaya lautan salah satunya adalah terumbu karang. (Wawancara, ON).

Berdasarkan hasil wawancara saya dengan bapak ON tersebut diatas dapat disimpulkan bahwa pembangunan pengelolaan terumbu karang telah dituangkan dalam RPJMD (Rencana Pembangunan Jangka Menengah Daerah) untuk mewujudkan visi misi pemerintah daerah yaitu mewujudkan surga nyata bawah laut. yang merupakan harga mati untuk mewujudkan pengelolaan terumbu karang yang berkelanjutan, karena terumbu karang tersebut merupakan salah satu potensi sumberdaya alam yang ada di Kabupaten Wakatobi yang tentunya digunakan potensi tersebut untuk kesejahteraan masyarakat.

\section{PENUTUP}

Berdasarkan hasil penelitian di atas dapat di simpulkan sebagai berikut: Inovasi pengelolaan terumbu karang yang dilakukan oleh Pemerintah Daerah dalam hal ini Dinas Kelautan dan Perikanan dalam mengatasi terhadap ancaman terjadinya degradasi terumbu karang serta mengeksploitasi potensi pemanfaatan terumbu karang agar menjadi nilai guna ekonomi bagi kesejahteraan masyarakat, yaitu diantara beberapa indikator inovasi pengelolaan terumbu karang adalah sebagai berikut bahwa: (1) keterlibatan pemangku kepentingan dapat aktif dalam melakukan transplantasi terumbu karang dan pengawasan laut. (2) berdasarkan pengetahuan lokal dan modern adalah bahwa tindakan pemerintah terdapat kesesuaian dengan pengetahuan lokal yaitu mengacu kepada nilai-nilai kearifan lokal dan memberdayakan masyarakat melalui pencaharian alternatif. Adapun secara moderen adalah bekerjasama dengan instansi universitas baik UNHALU Kendari maupun UNHAS Makassar serta para ahli dalam memperkenalkan transplantasi terumbu karang. (3) ada kendali terhadap segenap aktivitas yaitu membentuk pokmaswas (kelompok masyarakat pengawas) yang fungsinya melakukan pengawasan yang telah dikendalikan oleh pemerintah dinas DKP. (4). Alokasi sumberdaya yaitu dana yang bersumber dari APBN dan APBD yang dialokasikan kepada kegiatan pelatihan, transplantasi, serta melakukan operasi patroli pengawasan laut. (5) pilihan dan tujuan masyarakat adalah bahwa pilihan dan tujuan tersebut telah tercantum dalam visi misi pemerintah daerah karena visi tersebut bersumber dari budaya lokal dan dapat didukung oleh masyarakat. (6) Ada otoritas pengelolaan di dalamnya yaitu pengelolaan dengan berpedoman pada aturan pemerintah pusat dan kebijakan daerah termasuk juga peraturan desa (perdes) serta aturan adat dalam melakukan pengelolaan, pengawasan dan pemanfaatan terumbu karang. Adapun keberlanjutan terumbu karang adalah membentuk sistem penguatan kelembagaan dengan mekanisme kolaborasi antar instansi untuk melakukan penjagaan, pengawasan, pelestarian, dan pemanfaatan terumbu karang, serta pembangunan yang telah tercantum RPJMD dalam visi misi pemerintah daerah Kabupaten Wakatobi.

Faktor pendukung dalam meningkatkan inovasi pengelolaan terumbu 


\section{Vol. II, No. 2, Oktober 2012}

karang adalah adanya komitmen yang kuat dan terdapatnya kolaborasi dari pemerintah daerah maupun pemerintah pusat serta adanya dukungan dari seluruh komponen masyarakat adat, kelompok nelayan, stakeholder maupun instansi-instansi yang terkait yang konsen terhadap pelestarian dan pemanfaatan sumberdaya terumbu karang di Kabupaten Wakatobi. Adapun faktor penghambatnya adalah masih kurangnya kesadaran dari sebagian masyarakat, terbatasnya sarana dan prasaranan serta kurangnya dana dalam menjalankan operasi pengawasan untuk memantau dan menjangkau pada kawasan daerah-daerah perlindungan laut mengingat laut Wakatobi begitu luas serta sulitnya untuk menangkap para nelayan-nelayan yang datang dari luar daerah yang melakukan penangkapan ikan dengan cara illegal fishing maupun hal-hal yang bersifat destruktif lainya.

Berdasarkan hasil penelitian yang telah disimpulkan diatas, penulis mencoba memberikan saran yang kemudian bisa menjadi masukan bagi Pemerintah Daerah Wakatobi dalam hal ini Dinas Kelautan dan Perikanan dalam upaya memaksimalkan inovasi pengelolaan terumbu karang tersebut yaitu: Pemerintah daerah harus mengoptimalkan ke aktivitasnya lagi melalui sistem penguatan kelembagaan dan terus meningkatkan kolaborasi antar instasi yang terkait dalam melakukan penjagaan, pengawasan, pelestarian, pemanfaatan untuk peningkatan pengelolaan terumbu karang pada kawasan di daerah perlindungan laut agar pelaku ilegal fishing maupun yang dapat merusak terumbu karang lainya adalah dapat mengurangi terjadinya deskruktif atau bahkan benar-benar tidak terjadi lagi kerusakan terumbu karang di Kabupaten Wakatobi. Serta pemerintah daerah juga harus tingkatkan lagi kreativitas dan inovasi dalam mengatasi halhal yang dapat merusak terumbu karang serta mengembangkan potensi karang agar menjadi nilai ekonomi bagi kesejahteraan masyarakat.

\section{DAFTAR PUSTAKA}

Fattah, Nanang. 2004. Konsep Manajemen Berbasis Sekolah (MBS) dan Dewan Sekolah. Bandung: Pustaka Bani Quraisy.
Gunawan, dkk. 2006. pengenalan manfaat dan fungsi ekosistem terumbu karang dan ekosistem terkait, serta kondisi terumbu karang di indonesia. Jakarta : COREMAP II.

Iyam. 2007. Pemeliharaan Terumbu Karang. Bandung : Angkasa.

Ikawati, Y. dan H. Parlan. 2009. Coral reef in Indonesia. COREMAP II, MAPIPTEK dan Kemenko Kesra.

Kordik K, M Ghufran. 2010. Ekosistem Terumbu Karang. Jakarta: PT Rineka Cipta.

Kooiman, et. al. 2005. Fish for Life: Interactive Governanve for Fisheries. MARE Publications. University of Amsterdam Publishings.

Manullang, 2005. Dasar-Dasar Manajemen. Yogyakarta : Gadjah Mada University Press.Mardikanto, T. dan Sri Sutarni. T. 2001. Prosedur Penelitian Penyuluhan Pembangunan. Surakarta : Prima Theresia Pressindo.

Mokhsen, N. 2003. Decenralication in Indonesia. Thesis Ph D- Australian National University 2003.

Soediono, Gatot. 2008. Analisis Pengelolaan Terumbu Karang Pada Kawasan Konservasi Laut Daerah Pulau Randayan Dan Sekitarnya Kabupaten Bengkayang Provinsi Kalimantan Barat, Universitas Diponegoro, Semarang.

Thorbun, C. 2002. Regime change-prospects for community-based resource management in post- New Order Indonesia. Society and Natural Resources. 